\title{
Landscape structure, human disturbance and crop management affect foraging ground selection by migrating geese
}

\author{
Zuzanna M. Rosin • Piotr Skórka $\cdot$ Przemysław Wylegała $\cdot$ \\ Bartosz Krąkowski • Marcin Tobolka • Lukasz Myczko • \\ Tim H. Sparks $\cdot$ Piotr Tryjanowski
}

Received: 12 May 2011/Revised: 6 October 2011/Accepted: 17 November 2011/Published online: 9 December 2011

(C) The Author(s) 2011. This article is published with open access at Springerlink.com

\begin{abstract}
It is well known that agricultural intensification has caused severe population declines among bird species which use farmland for breeding and overwintering, while migrating bird species may benefit from intensive farming, but in turn damage crops. Knowledge of the habitat selection of migrating birds is important from both a conservation and agro-economic point of view. We investigated the habitat preferences of three common migrating goose species: White-fronted Goose Anser albifrons, Bean Goose A. fabalis and Greylag Goose A. anser during the autumn of 2009 in western Poland. A total of 24 flocks of these species were identified. Geese preferred large, elevated fields that were remote from forests and human settlements but in close proximity to a lake. Geese selected maize stubbles and avoided winter cereals. They selected sites in landscapes with a lower diversity of crops. Flock size was negatively correlated with the proportion of
\end{abstract}

Communicated by T. Gottschalk.

Z. M. Rosin $(\bowtie)$

Department of Cell Biology, Faculty of Biology,

Adam Mickiewicz University, Umultowska 89,

61-614 Poznań, Poland

e-mail: zuziarosin@o2.pl

P. Skórka

Institute of Environmental Sciences, Jagiellonian University,

Gronostajowa 7, 30-387 Kraków, Poland

P. Wylegała · B. Krąkowski

Polish Society for Nature Protection "Salamandra",

Stolarska 7/3, 60-788 Poznań, Poland

M. Tobolka - Ł. Myczko - T. H. Sparks - P. Tryjanowski Institute of Zoology, Poznań University of Life Sciences, Wojska Polskiego 71C, 60-625 Poznań, Poland pastures in the landscape, but it increased with field size, distance to forest and distance to town. Our results are in contrast with the paradigm that less intensive farmland positively influences habitat use by birds during foraging. We advise the delayed ploughing of stubbles with the aim of creating appropriate foraging habitats for geese and minimizing damage to cereal crops.

Keywords Habitat preference - Intensive farming - Crop damage $\cdot$ Maize stubble $\cdot$ Human disturbance $\cdot$ Anser spp

\section{Zusammenfassung}

Landschaftsstruktur, menschliche Störung und Anbaumethoden beeinflussen die Nahrungsflächenwahl wandernder Gänse

Die Intensivierung der Agrarwirtschaft hat starke Populationsrückgänge sowohl brütender als auch überwinternder Vogelarten in landwirtschaftlich genutzten Flächen verursacht. Dennoch können ziehende Vogelarten von der intensiven Landwirtschaft profitieren, aber auch Kulturpflanzen schädigen. Sowohl aus Sicht des Naturschutzes, als auch aus agrarökonomischer Sicht ist es wichtig, Kenntnisse über die Habitatwahl der Gänse zu erlangen. Vor diesem Hintergrund untersuchten wir im Herbst 2009 in Westpolen die Habitatpräferenzen dreier häufiger und ziehender Gänsearten: Blässgans Anser albifrons, Saatgans Anser fabalis und Graugans Anser anser. Insgesamt fanden wir 24 Trupps dieser Arten. Die Gänse bevorzugten große, erhöhte Felder, die in der Umgebung eines Sees und abseits von Wäldern und menschlichen Siedlungen lagen. Die Gänse wählten Maisstoppeln und mieden Wintergetreide. Sie selektierten Gebiete in Landschaften mit einer geringen 
Diversität an Anbaupflanzen. Die Truppgröße war negativ korreliert mit dem Grünlandanteil der Landschaft. Truppgrößen erhöhten sich mit der Feldgröße und mit den Distanzen zu Wäldern und Siedlungen. Unsere Ergebnisse stehen im Gegensatz zum Paradigma, dass weniger intensive Landnutzung die Habitatnutzung der Vögel während der Nahrungssuche positiv beeinflusst. Wir empfehlen ein verspätetes Pflügen der Stoppeln, um geeignete Nahrungshabitate für Gänse zu schaffen und damit die Schädigung von Getreidepflanzen zu minimieren.

\section{Introduction}

Many bird species which breed and overwinter in farmland habitats have suffered severe population declines in recent decades (Donald et al. 2006). It is generally acknowledged that agricultural intensification with associated breeding habitat loss and deterioration are the major causes of these declines in numbers (Nagy et al. 2009; Rodríguez-Teijeiro et al. 2009). However, much less attention has been paid to species that select various farmland habitats during migration (Lindström et al. 2010). Moreover, there are several bird species that might benefit from intensive agricultural landscapes during migration, such as the Golden Plover Pluvialis apricaria (Lindström et al. 2010), the Common Crane Grus grus (Leito et al. 2008) and geese (e.g., Fox et al. 2005; Van der Graaf et al. 2007; Jensen et al. 2008), and which in turn may have important impacts on ecosystem processes and the agro-economy. Consequently, understanding how such migratory birds select foraging sites during migration is desirable (Lindström et al. 2010; Sebastian-González et al. 2010; Batáry et al. 2011).

The selection of foraging habitat during migration is central to the life history of these birds and greatly influence their fitness (Cody 1985; Farmer and Wiens 1999; Drent et al. 2006; Duriez et al. 2009). Migrating birds depend mostly on the availability of resources at stopover sites that influence survival and recuperation (Bauer et al. 2008; Alerstam 2011). Although many studies have focused on the physiology of migration and strategies for energy refuelling (e.g., Tinkler et al. 2009; Guglielmo 2010), much less is known about site choice where birds forage (Newton 2006).

The selection of foraging sites by birds in agricultural landscapes is highly influenced by human-related factors (Olsson et al. 2002; Madsen and Boertmann 2008). Firstly, human disturbance may directly affect bird behaviour (Sirot 2010) and probably thereby their strategies of feeding site choice. Secondly, predation pressure may be mediated by human-related management of agricultural landscapes (e.g., Pita et al. 2009; Wang et al. 2011). Landscape composition also affects the foraging decisions of animals (Cresswell and Osborne 2004; Skórka et al. 2009). Migrating birds foraging in agricultural landscapes may seek foraging patches rich in resources, such as pastures and/or set-aside or unploughed fields (Olsson et al. 2002; Lindström et al. 2010). The identification of these sites and an understanding of which factors affect their selection by birds may be of key importance for land management, successful conservation and reduced crop damage (Jensen et al. 2008).

Most goose populations in the Western Palaearctic have recovered substantially during the last three to five decades (Madsen et al. 1999; Andersson et al. 2001). This has led not only to the expansion of their breeding range, but also to an increase in the number and size of migrating and wintering goose flocks and, in turn, to damage to crops and other complaints of nuisance (e.g., Roomen and van Madsen 1992). However, current goose population trends vary in different areas (Lawicki et al. 2010). Additionally, large concentrations of goose flocks are recognized as one of the criteria to create Natura 2000 areas (Council Directive 2009). Among 174 Important Bird Areas of international importance in Poland, 21 were created especially to conserve migrating and wintering Bean Goose Anser fabalis and 13 for White-fronted Goose Anser albifrons based on the criteria of BirdLife International (2004) and Wilk et al. (2010). However, in many European countries, the most numerous migrating geese species, namely, the White-fronted Goose, Bean Goose and Greylag Goose A. anser, are game species (Council Directive 2009). Thus, there are often conflicts between goose conservation and measures aimed at controlling their numbers in farmland (Jensen et al. 2008).

The aim of this paper was to further our understanding of foraging site selection by migrating geese in agricultural landscapes in western Poland. Using a general approach, we studied how agricultural methods, crop diversity at the landscape scale, human-related factors, forests and lakes, and site elevation affected the foraging habitat choice of three species of migratory geese.

\section{Methods}

\section{Bird surveys}

Eight large plots $\left(100 \mathrm{~km}^{2}\right)$ were selected (through the generation of random geographical coordinates in QuantumGIS software) as study areas in agricultural landscapes in western Poland (Fig. 1). This is the most important agricultural region in Poland (Jankowiak et al. 2003; Tryjanowski et al. 2011) and is representative of the main 


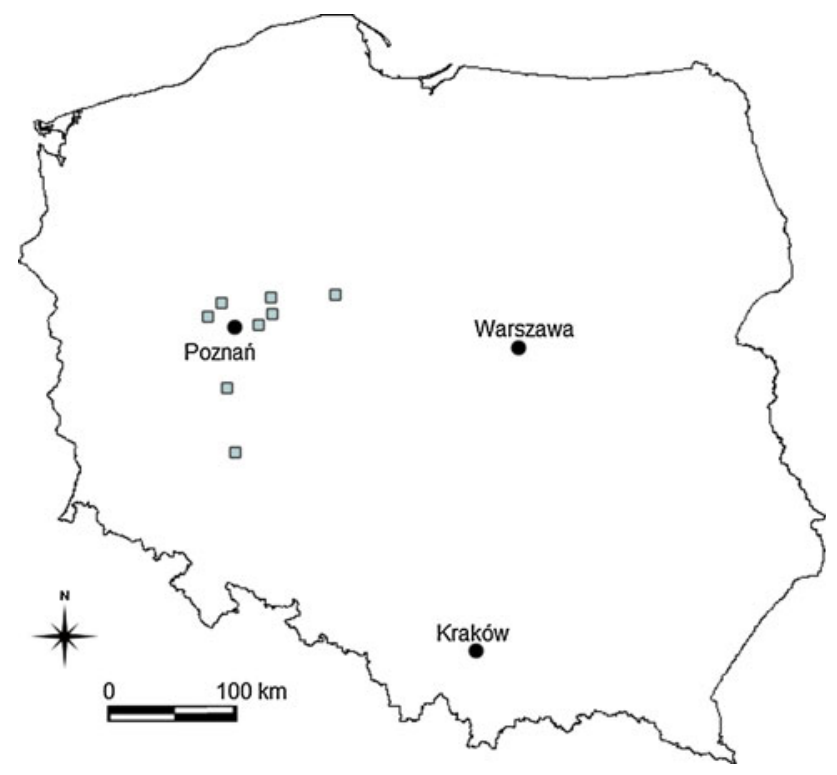

Fig. 1 Map of Poland showing the location of the study plots (grey squares)

staging and wintering goose areas in Central Europe (Lawicki et al. 2010). The preferred type of agriculture activities in Wielkopolska is cereal crop farming and cattle and pig breeding, but areas of intensive cultivation have been expanding recently. On a national scale, the region dominates the production of sugar beet and other vegetable crops (Jankowiak et al. 2003). During the autumn of 2009 (October-November), the plots were surveyed from cars. Within each plot, observers stopped several times to search for geese using binoculars $(10-12 \times 50)$ and telescopes $(30-60 \times)$. The observation points were arranged so that the entire plot area was covered by visual observation. One count, lasting approximately $5 \mathrm{~h}$, was conducted in each plot. The surveys were conducted during favourable weather conditions (no rain or snowfall). When a goose flock was found, its species composition, the number and age of birds, as well as the geographical coordinates of the site were noted. We counted birds from a distance so as not to disturb their foraging and movements.

Habitat and landscape characteristics of the foraging sites

In the sites where geese were found we measured several variables that potentially could influence site-selection by the birds (Table 1).

In general, variables 1-9 (Table 1) describe foraging habitat (foraging patch size and availability of various food resources) since geese often forage in agricultural areas. Variables 10-13 were indicators of human disturbance/ pressure. We distinguished between local roads and regional/national roads because the former are characterized by little traffic (usually much fewer than 100 vehicles per hour), whereas the latter represent roads with $>500$ vehicles per hour (authors' unpublished observations). Variables 14-15 may be indicators of the site's safety from predators, variables 16-17 describe the proximity of roosting areas or migration/dispersal corridors, as has been demonstrated for other waterbirds (Skórka et al. 2009; Maciusik et al. 2010). The lake size of 10 ha was chosen because it was the smallest lake where roosting geese were observed in the area (authors' unpublished observations).

To check if the geese preferred any of these features we selected random sites equal in number to the number of geese flocks $(n=24)$. We selected random geographical coordinates within the plot boundaries. In a given plot, the number of random sites was equal to the number of geese flocks found there. At random points we measured the same variables as for geese flocks (Table 1).

Variables 1, 10-14 and 16-17 (Table 1) were measured from satellite images and calculated in ImageJ and QuantumGIS software. Variables 2-8 and 14 were derived by direct mapping in the field. We recorded crop type on the maps during field surveys and, later, scans of these maps were digitalized in QuantumGIS software. Variable 9 was calculated in the BioDiversity Pro Software (McAleece 1997).

\section{Data processing and statistical analysis}

To test whether geese had preferences for crop type during foraging, we used Fisher's exact test and compared the number of observations of geese flocks in different crops with the equivalent from random points (expected numbers). If geese had no preferences for crop type, the number of flocks and number of random points in a given crop type should be similar. The same test was used to check if geese had preferences for an elevation category.

To compare whether sites where geese foraged differed in landscape composition from random sites, we used general linear mixed models (GLMM). We tested if the mean values of the environmental variables measured at sites selected by geese differed from mean values at random sites. The categorical independent variable was foraging or random site. Because observations were conducted in eight large plots, we assigned their identity as a random effect to account for spatial autocorrelation (Dormann et al. 2007).

Spatial autocorrelation was tested by Moran's local indicator (Legendre and Legendre 1998). The spatial autocorrelation value at a given distance class indicates how predictable (positively or negatively) the measured variable (goose flock size in our study) was at a given point 
Table 1 Codes of the habitat and landscape variables measured at random points and of sites selected by geese for foraging during the autumn

\begin{tabular}{|c|c|c|}
\hline Number & Code & Characteristics \\
\hline 1 & FieldSize & Field size (ha) \\
\hline 2 & PPloughed & Percentage cover of ploughed land in a 500-m radius from the centre of the foraging flock \\
\hline 3 & PBeet & Percentage cover of beet stubble in a $500-\mathrm{m}$ radius \\
\hline 4 & PRape & Percentage cover of rape stubble in a $500-\mathrm{m}$ radius \\
\hline 5 & PMaize & Percentage cover of maize stubble in a $500-\mathrm{m}$ radius \\
\hline 6 & PWinterCere & Percentage cover of winter cereals in a $500-\mathrm{m}$ radius \\
\hline 7 & PPastures & Percentage cover of pasture in a $500-\mathrm{m}$ radius \\
\hline 8 & PSetAside & Percentage cover of set-aside in a $500-\mathrm{m}$ radius \\
\hline 9 & HabitatDiver & $\begin{array}{l}\text { Simpson reciprocal diversity index (1/D) calculated from the percentage cover of crops (Simpson 1949). The value of } \\
\text { this index has } 1 \text { as the lowest possible figure. This figure would represent a composition containing only one cover } \\
\text { type. The higher the value, the greater the diversity of crop types }\end{array}$ \\
\hline 10 & DLocRoad & Distance $(\mathrm{m})$ to the nearest local road from the centre of the foraging flock \\
\hline 11 & DRegRoad & Distance $(\mathrm{m})$ to the nearest regional/national road \\
\hline 12 & DHumanS & Distance $(m)$ to the nearest human settlement \\
\hline 13 & DTown & Distance $(\mathrm{km})$ to the nearest town withe $>5,000$ citizens \\
\hline 14 & DForest & Distance $(m)$ to the nearest forest \\
\hline 15 & Elevation & $\begin{array}{l}\text { Site elevation, coded as a simple categorical variable: }-1 \text { (a site located below the surrounding area), } 0 \text { (a site located } \\
\text { at the same elevation as the surrounding landscape), } 1 \text { (a site at a higher elevation than the surrounding landscape). } \\
\text { The classification was based on the prevailing elevation of landscape in a radius of } 500 \mathrm{~m} \text { from the centre of the } \\
\text { foraging flock (e.g., if } 60 \% \text { of the landscape within } 500 \mathrm{~m} \text { was below elevation of the site selected by the flock it was } \\
\text { classified as elevated and coded as (1) }\end{array}$ \\
\hline 16 & DRiver & Distance $(\mathrm{m})$ to the nearest river longer than $50 \mathrm{~km}$ \\
\hline 17 & DLake & Distance $(\mathrm{m})$ to the nearest lake $>10$ ha \\
\hline
\end{tabular}

of the sampling framework. Moran's index varies between -1 and 1 , with non-significant values close to zero.

To test whether the number of geese was dependent on measured variables, we used modified Pearson correlation coefficients that take into account the pattern in spatial autocorrelation (Dutilleul 1993).

We did not build multivariate models because the number of geese flocks was low (in a statistical sense) compared to the number of variables that potentially affected site choice and flock size. Instead, we examined in detail Pearson spatial correlation coefficients between the continuous explanatory variables to identify possible confounding effects due to multicollinearity. This could lead to biased statistically significant results of GLMM resulting simply from strong correlations between environmental variables. When collinearity between two variables was found, we calculated a simple regression between them, and residuals (part of the variation of one variable not explained by the second) were included in the GLMM. The GLMMs were built in the same manner as described above.

The GLMMs and correlation analyses are sensitive to outliers; therefore, where necessary, data were $\log _{10}$ or $\log _{10}(x+1)$ transformed to minimize effects of the outliers and to homogenize variances (Quinn and Keough 2002). The Grubbs tests (Grubbs 1969) indicated that the analyses based on raw and logarithmically transformed data (in the case of skewed distributions) were not affected by outliers (all $P>0.100$ ). Variables expressed as proportions were arcsin-transformed. Corrected means calculated on $\log _{10^{-}}$ transformed data and then back-transformed in the case of skewed distributions are presented throughout the paper (Quinn and Keough 2002). Means are given with their 95\% confidence intervals (CIs) that are also calculated on $\log _{10^{-}}$ transformed data where necessary, and then back-transformed (and hence will be asymmetric).

All calculations were done in JMP 9 (2010) and SAM 4.0 (Rangel et al. 2010) software.

\section{Results}

Foraging flock size, species composition, and spatial autocorrelation

We noted 24 goose flocks during the surveys. The mean number of flocks per plot was 3.0 (95\% CI 1.4-4.4, median 2.5, range 1-6 flocks per plot). Three goose species were present in the flocks: White-fronted Goose, Bean Goose and Grey-lag Goose (Table 2). Overall, 40,926 birds were counted during surveys. The Bean Goose was the most 
Table 2 Frequency of goose species in flocks and their abundance

\begin{tabular}{llllrr}
\hline Goose species & $\begin{array}{l}\text { Frequency in } \\
\text { flocks }(n=24)\end{array}$ & \multicolumn{2}{l}{ Number of individuals per flock } \\
\cline { 3 - 5 } & & Mean & Lower-upper 95\% CI & Median & Range \\
\hline White-fronted goose $^{\mathrm{a}}$ & 23 & 175.9 & $114.0-271.6$ & 200 & $30-1,200$ \\
Bean goose $^{\mathrm{a}}$ & 22 & 895.7 & $574.8-1,395.7$ & 800 & $180-5,500$ \\
Grey-lag goose $^{\mathrm{a}}$ & 7 & 108.9 & $16.3-729.7$ & 309 & $2-400$ \\
\hline
\end{tabular}

${ }^{a}$ Both means and $95 \%$ confidence intervals (CIs) were calculated on $\log _{10}$-transformed data and then back-transformed

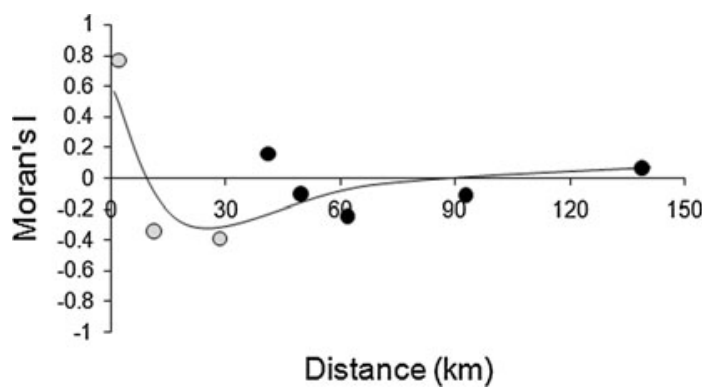

Fig. 2 Spatial autocorrelogram for goose flock size. Grey circles spatial autocorrelations significant at $P \leq 0.05$

numerous ( $80.8 \%$ of all individuals), with the Whitefronted Goose and Grey-lag Goose being much less numerous (15.0 and $4.2 \%$ of all individuals, respectively; Table 2). Mean goose flock size was 1,166.4 birds (95\% CI $787.0-1,728.6$, median size 1,375 , range $236-5,800$ ). We found a significant positive spatial autocorrelation in flock size of geese at small distances $(2 \mathrm{~km})$ and a statistically significant negative spatial autocorrelation at distances of 10-30 km (Fig. 2).

Habitat and landscape factors affecting foraging site selection by geese

Sites selected by geese were more often located on maize stubbles than expected by chance (from crop types found at random sites; Fisher exact test $P<0.001$; Fig. 3). Sites selected by foraging geese were more often located at higher elevation in relation to the surrounding landscape than expected by chance (Fisher exact test $P<0.001$; Fig. 4), and fields selected by foraging geese were on average larger than expected (Table 3 ). Sites selected by geese were located in a landscape with a higher cover of maize stubble and a lower cover of ploughed fields and winter cereals (Table 3). When we took the cover of all crop types and calculated their diversity within a landscape, we found that geese selected sites in landscapes with a lower diversity of crops (Table 3). Sites selected by foraging geese were on average more distant from human settlements, local roads and forests than random sites

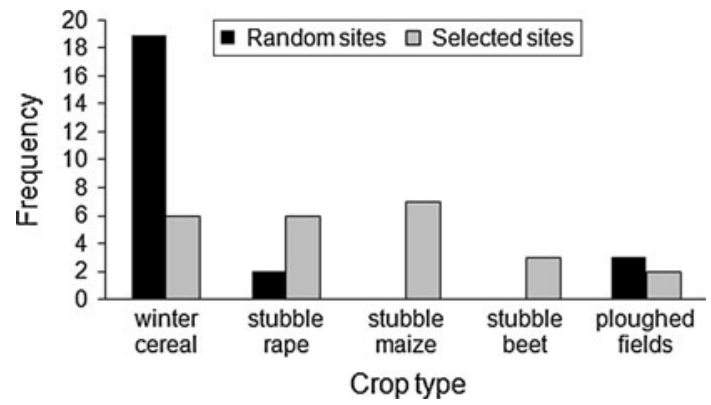

Fig. 3 Preferences of foraging geese to different crop types (including ploughed fields). Black bars crops at random points, grey bars crops at which flocks of foraging geese were noted. Number of geese flocks and random sites were both $n=24$

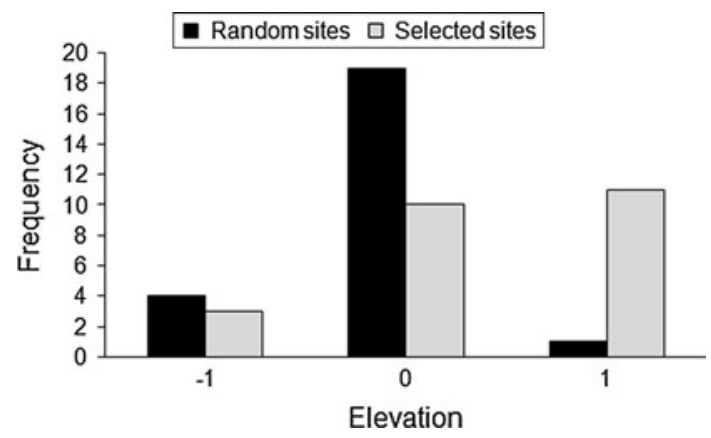

Fig. 4 Preferences of foraging geese to different elevations of the site. Black bars Elevation at random points, grey bars elevation at sites where flocks of foraging geese were noted. Elevation was coded as a categorical variable: -1 a site below the elevation of the surrounding area, $O$ a site at the same elevation as the surrounding landscape, 1 a site higher than surrounding landscape. Number of geese flocks and random sites were both $n=24$

(Table 3). Furthermore, sites selected by foraging geese were closer to lakes than randomly selected sites (Table 3).

Factors affecting flock size of foraging geese

The size of goose flocks was positively correlated with field size, distance to nearest forest and distance to the nearest town, but negatively correlated with proportion of pasture in the landscape (Table 4; Fig. 5). When we 
Table 3 Habitat and landscape characteristics of the random points and of sites selected by geese for foraging during the autumn

\begin{tabular}{|c|c|c|c|c|c|c|c|}
\hline \multirow[t]{2}{*}{ Variable } & \multicolumn{2}{|c|}{ Random points } & \multicolumn{2}{|c|}{ Foraging sites } & \multirow[t]{2}{*}{ GLMM $F$} & \multirow[t]{2}{*}{$d f$} & \multirow[t]{2}{*}{$P$} \\
\hline & Mean & $\begin{array}{l}\text { Lower-upper } \\
95 \% \text { CI }\end{array}$ & Mean & $\begin{array}{l}\text { Lower-upper } \\
95 \% \text { CI }\end{array}$ & & & \\
\hline FieldSize (ha) ${ }^{\mathrm{a}}$ & 7.2 & $4.6-11.1$ & 21.5 & $14.0-32.8$ & 16.177 & $1,39.0$ & $<0.001^{*}$ \\
\hline PPloughed $(\%)^{\mathrm{a}}$ & 9 & $7-12$ & 3 & $1-5$ & 13.351 & $1,39.7$ & $0.007 *$ \\
\hline PBeet $(\%)^{\mathrm{a}}$ & 1 & $0-2$ & 3 & $0-7$ & 3.012 & $1,36.8$ & 0.091 \\
\hline PRape $(\%)^{\mathrm{a}}$ & 12 & $7-18$ & 24 & $16-34$ & 3.791 & $1,41.4$ & 0.060 \\
\hline PMaize $(\%)^{\mathrm{a}}$ & 5 & $1-9$ & 16 & $10-21$ & 4.126 & $1,42.1$ & $0.048^{*}$ \\
\hline PWinterCere $(\%)^{\mathrm{a}}$ & 52 & $47-58$ & 35 & $26-46$ & 5.569 & $1,37.5$ & $0.024 *$ \\
\hline PPastures $(\%)^{\mathrm{a}}$ & 5 & $2-8$ & 4 & $1-8$ & 0.786 & $1,44.9$ & 0.380 \\
\hline PSetAside (\%) & 3 & $1-6$ & 1 & $0-2$ & 4.244 & $1,43.8$ & 0.450 \\
\hline HabitatDiver $(\%)^{\mathrm{a}}$ & 2.57 & $2.33-2.82$ & 2.11 & $1.94-2.32$ & 5.485 & $1,38.9$ & $0.024 *$ \\
\hline DLocRoad (km) & 0.22 & $0.17-0.27$ & 0.46 & $0.35-0.60$ & 17.443 & $1,42.4$ & $<0.001 *$ \\
\hline DRegRoad $(\mathrm{km})^{\mathrm{a}}$ & 1.75 & $1.16-2.496$ & 2.11 & $1.60-2.72$ & 1.656 & $1,28.9$ & 0.208 \\
\hline DHumanS $(\mathrm{km})^{\mathrm{a}}$ & 0.33 & $0.25-0.42$ & 0.51 & $0.42-0.62$ & 4.046 & $1,42.2$ & $0.050^{*}$ \\
\hline DTown (km) & 6.87 & $5.25-8.49$ & 7.95 & $6.21-9.69$ & 2.802 & $1,39.2$ & 0.102 \\
\hline DForest $(\mathrm{km})$ & 1.02 & $0.67-1.36$ & 2.31 & $1.89-2.73$ & 22.568 & $1,44.9$ & $<0.001 *$ \\
\hline DRiver $(\mathrm{km})^{\mathrm{a}}$ & 3.06 & $2.20-4.11$ & 4.02 & $2.83-5.57$ & 2.106 & $1,38.9$ & 0.155 \\
\hline DLake (km) & 2.79 & $2.19-3.39$ & 1.64 & $1.14-2.13$ & 10.110 & $1,42.5$ & $0.003^{*}$ \\
\hline
\end{tabular}

Data are the results of univariate generalized linear mixed models (GLMM)

For explanation of the variables: see Table 1

* Significant results at $P<0.05$

${ }^{a}$ Both means and $95 \%$ confidence intervals (CIs) were calculated on $\log _{10}$-transformed data and then back-transformed

Table 4 Pearson correlation coefficients adjusted for spatial autocorrelation $(P$ value in brackets) between number of individuals of all geese species, number of individuals of particular species and habitat and landscape features measured at sites selected by geese
$*$ Significant correlations at
$P<0.05$

For explanation of the variables: see Table 1

\begin{tabular}{lcccr}
\hline Effect & All species & $\begin{array}{l}\text { White-fronted Goose } \\
(n=23 \text { flocks })\end{array}$ & $\begin{array}{l}\text { Bean goose } \\
(n=22 \text { flocks })\end{array}$ & $\begin{array}{r}\text { Grey-lag goose } \\
(N=7 \text { flocks })\end{array}$ \\
\hline FieldSize & $0.460(0.050)^{*}$ & $0.283(0.199)$ & $0.379(0.094)$ & $0.318(0.178)$ \\
PPloughed & $-0.379(0.105)$ & $-0.081(0.775)$ & $-0.386(0.138)$ & $0.120(0.687)$ \\
PBeet & $-0.230(0.275)$ & $-0.269(0.191)$ & $-0.151(0.449)$ & $-0.286(0.203)$ \\
PRape & $0.060(0.810)$ & $0.050(0.791)$ & $0.071(0.768)$ & $0.021(0.920)$ \\
PMaize & $0.430(0.167)$ & $0.238(0.225)$ & $0.399(0.199)$ & $-0.065(0.774)$ \\
PWinterCere & $-0.090(0.591)$ & $0.092(0.652)$ & $-0.133(0.353)$ & $0.200(0.326)$ \\
PPastures & $-0.467(0.031)^{*}$ & $-0.381(0.037)^{*}$ & $-0.387(0.104)$ & $-0.135(0.504)$ \\
PSetAside & $-0.149(0.392)$ & $-0.064(0.785)$ & $-0.125(0.498)$ & $-0.153(0.504)$ \\
HabitatDiver & $-0.391(0.132)$ & $-0.110(0.630)$ & $-0.381(0.169)$ & $0.010(0.971)$ \\
DLocRoad & $0.208(0.243)$ & $0.459(0.035)^{*}$ & $0.088(0.643)$ & $0.284(0.212)$ \\
DRegRoad & $0.366(0.107)$ & $0.300(0.242)$ & $0.478(0.044) *$ & $0.360(0.159)$ \\
DHumanS & $0.480(0.107)$ & $0.144(0.439)$ & $0.477(0.116)$ & $-0.130(0.529)$ \\
DTown & $0.716(0.015)^{*}$ & $0.382(0.195)$ & $0.650(0.034)^{*}$ & $0.075(0.797)$ \\
DForest & $0.677(0.002)^{*}$ & $0.677(0.003)^{*}$ & $-0.043(0.858)$ & $0.570(0.045)^{*}$ \\
DRiver & $0.036(0.903)$ & $-0.109(0.619)$ & $0.078(0.804)$ & $-0.173(0.522)$ \\
DLake & $0.436(0.171)$ & $-0.100(0.699)$ & $0.496(0.128)$ & $-0.245(0.267)$ \\
\hline
\end{tabular}

analysed numbers of particular species within foraging flocks, we found that the number of White-fronted Goose was positively correlated with distance to the nearest local road and distance to the nearest forest but negatively correlated with the proportion of pasture in the landscape (Table 4; Fig. 5). The number of Bean Goose was positively correlated with distance to the nearest regional road and distance to the nearest town (Table 4; Fig. 5), and the 

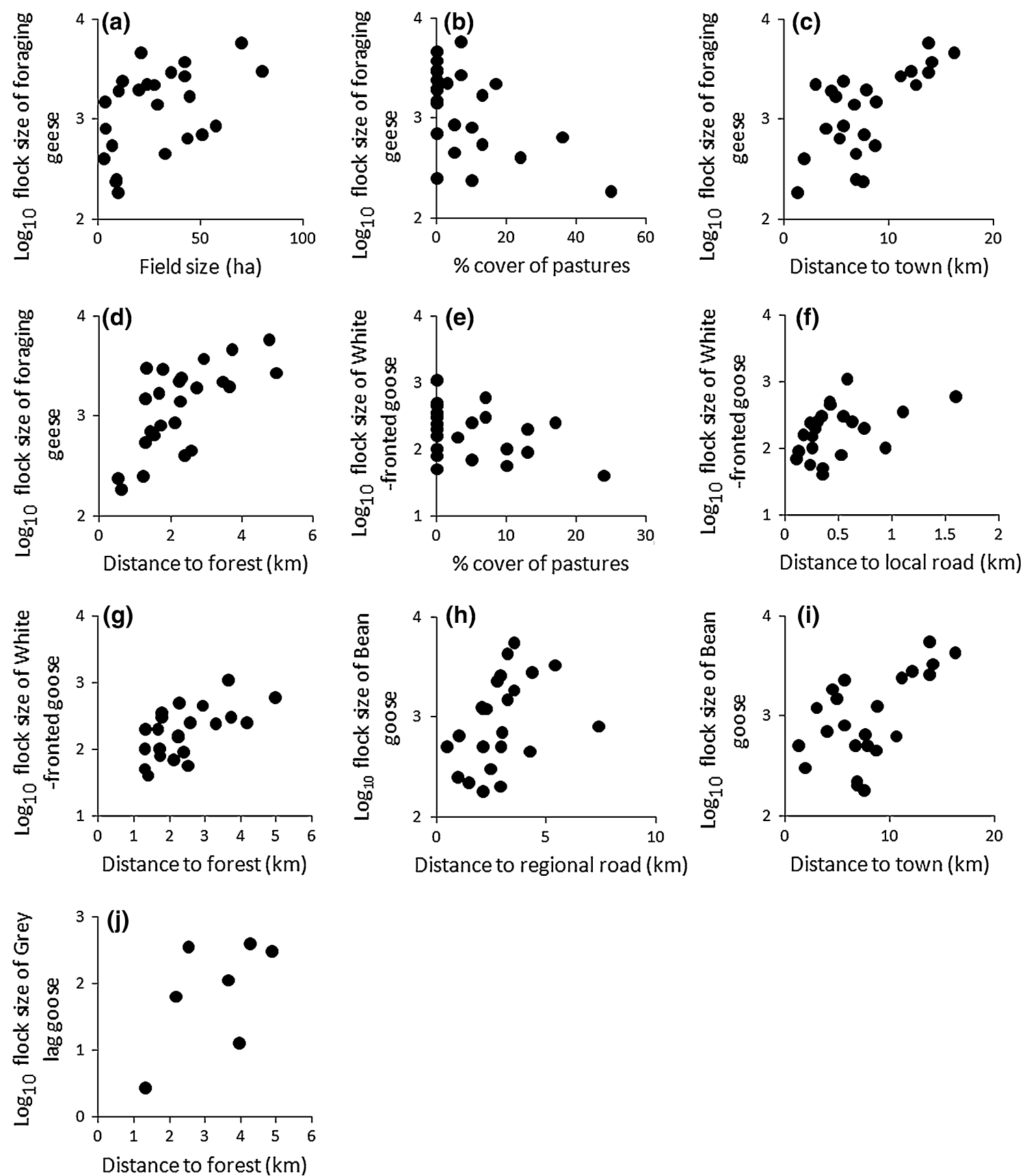

Fig. 5 Statistically significant correlations between geese flock size and field size (a), cover of pastures in a landscape (b), distance to nearest town (c) and distance to nearest forest (d). Analyses for individual species showed that flock size of White-fronted Goose Anser albifrons were significantly correlated with cover of pastures $(\mathbf{e})$, distance to local

road (f) and distance to forest (g). Flock size of the Bean Goose A. fabalis correlated with distance to local road (h) and distance to town (I). Flock size of Grey-lag Goose A. anser correlated with distance to forest (j)

number of Grey-lag Goose was positively correlated with distance to the nearest forest (Table 4; Fig. 5).

Multicollinearity between environmental variables and analysis of residuals

We found five statistically significant correlation coefficients between variables (Appendix). Cover of ploughed

fields and cover of winter cereals were negatively correlated. The GLMM based on residuals not explained by the cover of winter cereals revealed that sites selected by geese had a lower cover of ploughed fields than random sites $\left(F_{1,39.8}=16.55, P<0.001\right)$. We also found two statistically significant correlation coefficients between habitat diversity index and the cover of ploughed fields, and between diversity and the cover of winter cereals. However, since the 
index is composed from the other variables, this correlation was not unexpected. Therefore, it made little sense to calculate residuals between these variables and conduct a GLMM. We found two additional statistically significant correlation coefficients (Appendix); however these correlations did not lead to false significant results in our GLMMs because rape cover and distance to the river were similar in sites selected by geese and random sites (see Table 3; Appendix).

\section{Discussion}

Our results show that geese foraging in farmland during the autumn migration in western Poland select specific crops and sites located in areas guaranteeing low disturbance both by predators and humans. Contrary to most studies on declining farmland bird populations during the breeding season, geese selected those parts of farmland that were intensively managed, preferring larger field sizes and lower crop diversity. Flocks of foraging geese also had a predictable spatial structure, as indicated by spatial autocorrelations.

\section{Crop preferences of geese}

We found that geese avoided fields of winter cereals but were frequently found at stubbles of maize, beet and rape (as revealed by Fisher exact tests). These preferred crop types were found much less often at randomly chosen sites. Moreover, a cover of maize stubbles in a landscape positively affected site choice by geese, whereas the opposite result was found for a cover of winter cereals and ploughed fields. Stubbles are favourite foraging sites even when their share in a landscape is low (Madsen 1985a; Jepsen 1991; Gill 1996). For example, geese have been found to prefer stubbles of beet (Gill 1996; Gill et al. 1997; Nilsson and Persson 2000), maize (Frederick and Klaas 1982) and rape (Nilsson and Persson 2000). The preference for these crop types may be easily explained by the high energy value of these food types, which are needed to build up the reserves during the autumn migration (Raveling 1979). During harvesting, many corn cobs drop to the ground, and some plant material is also left, providing a good source of energy for geese. Moreover, geese may forage on weeds growing among maize stems (Reed et al. 1977; Frederick and Klaas 1982). However, the preferences of geese for winter cereals differ between studies; for example, Nilsson and Persson (2000) considered this crop type to be an important food type for geese, whereas Jepsen (1991) found the opposite. These differences might be due to different crop availability and/or weather conditions since it has been proven that geese graze on winter cereals when stubbles are ploughed or the ground is frozen (Nilsson and Persson 1991). It has also been shown that the change from their natural food, Scirpus tubers, to agricultural areas was gradual and that geese first turned to crops similar to their natural food (pasture, winter cereals) but gradually learned to take advantage of various crop types rich in energy (Gill et al. 1997; Prop et al. 1998; Nilsson and Persson 2000).

\section{Spatial pattern in flock size}

We detected significant spatial autocorrelation in the size of flocks. Spatial autocorrelation may lead to increased type I error in analyses and the determination of too many significant effects (Dormann et al. 2007). However, we accounted for this problem in almost all our analyses. In a biological sense, spatial autocorrelation may lead to spatial synchrony that indicates coincident numbers of individuals (Liebhold et al. 2004). In our study, we found significant positive spatial autocorrelation for the flock size at distances up to $2 \mathrm{~km}$. Spatial autocorrelation was also found in a study on Pink-footed Goose in Norway (Jensen et al. 2008). Taken together, these results indicate that there is some similarity in the size of flocks foraging close together in the landscape. This similarity may result from sites located close to each other having a more similar landscape structure than those further apart. If geese prefer specific landscape features (e.g. field size), their flocks may be spatially bound to these features which, in turn, limits flock sizes (Spilling et al. 1999), leading to the observed pattern of spatial autocorrelation. We believe that the odds of counting the same flock twice were minimal because we did not disturb foraging birds and one plot was visited only once within a restricted time framework. Therefore, the spatial autocorrelation found in our study likely did not result from the movements of individuals.

Predators and/or disturbance during foraging in farmland

In this study we documented that geese probably chose sites that were higher than the surrounding landscape. We believe that this result is linked with predation or disturbance avoidance. Foraging animals must cope with the potential risk of predation (Lima 1998; Jonker et al. 2010). Sites that allow the early detection of approaching predators should therefore be preferred (Lima 1987; McNamara and Houston 1992), and higher elevation inevitably enables geese to observe what is going on in their surroundings. The study of Madsen (1985b) also indicated that geese avoid sites with limited visibility. However, it has also 
been reported that some goose species, such as the Pinkfooted Goose, avoid sites located at higher elevation in farmland (Jensen et al. 2008). Our landscape plots were located in a lowland region (50-152 m a.s.l) with little variation in elevation. It is possible that geese generally prefer regions located at low elevation, but within a given region, they choose sites slightly raised above the surrounding landscape. In our study, the scale at which relative elevation was measured was quite simple, but there is no other good method to measure relative elevation at the given sites. The effect of site elevation in relation to the surrounding landscape should be incorporated in a more sophisticated manner in future studies on the landscape ecology of geese.

Geese were found to avoid the proximity of forests. This result may also be explained by predator avoidance. In Poland, forest edges and small mid-field forests are a major habitat of the opportunistic Red Fox Vulpes vulpes (Tryjanowski et al. 2002; Jankowiak et al. 2008) are used as well by the White-tailed Eagle Haliaeetus albicilla that preys on geese (Roder et al. 2008) and whose appearance causes entire goose flocks to take flight (personal observations). Other explanations for avoidance of forest edges is that hunters often hunt from hides at forest edges and forestry workers may occasionally work and appear at forest edges, thereby disturbing geese foraging nearby (Klaassen et al. 2006).

We found that sites selected by geese were more distant from roads and human settlements. In our study, geese avoided local roads, but we did not find an effect of the presence of regional roads with higher traffic. In fact, local roads were, on average, closer to foraging sites than regional roads, and it has been shown, for example, that the Pink-footed Goose A. brachyrhynchus responds negatively to even very little road traffic and rarely forages in fields close to roads (Madsen 1985b; Gill 1996; Jensen et al. 2008). Although the proximity of regional roads did not affect foraging site choice in our study, it was an important factor influencing flock size of the Bean Goose, with the flock size of this species being larger in fields further from these roads. This is an interesting result and suggests that road traffic may affect the social behaviour of the studied species. Human settlements negatively affected foraging site selection by geese in farmland. The effect may be linked with two phenomena. Firstly, farmers and local inhabitants may directly disturb foraging birds around their properties due to normal human activity or by implementing scaring practices to protect crops (Tombre et al. 2005; Klaassen et al. 2006; Jensen et al. 2008). Secondly, there is an abundance of freely roaming dogs and cats in Polish villages. Wandering dogs in particular may be a real threat to foraging geese, resulting in increased vigilance
(Randler 2006). It has been shown that domestic dogs, as well as foxes, operate mostly in the neighbourhood of human settlements (Jankowiak et al. 2008; Olko et al. 2009). We also found an interesting effect of town proximity on the flock size of foraging geese. Flock size increased with increasing distance to the town. To the best of our knowledge this is the first such result found for geese. Towns are associated with greater human activity and higher road traffic, both of which probably disturb flocking behaviour during migration.

The proximity of lakes positively affected the use of farmland by geese during migration. During migration, lakes are usually used by geese as roosting and daily resting sites. This may explain the positive effect of this habitat on the presence of geese in farmland. Other authors have also found that geese primarily use fields close to roosting sites (e.g., Gill 1996; Jensen et al. 2008).

Is a less intensive farmland habitat always beneficial for birds?

Agricultural intensification has led to a loss of habitat heterogeneity and increased field size (Benton et al. 2003; Reif et al. 2010) and, as a consequence, to a widespread decline in farmland biodiversity across many different taxa (Donald et al. 2001; Fuller et al. 2004). In the context of foraging behaviour, loss of habitat heterogeneity may also diminish the availability of food resources for foraging farmland birds (Surmacki 2005; Wilson et al. 2005).

Our results are in sharp contrast with the paradigm that a less intensive use of farmland (greater habitat heterogeneity and small field sizes) positively influences habitat use during foraging. Geese chose sites characterized by a lower diversity of crop types and preferentially foraged on fields that were larger than those generally available. Flock size was also greater on larger fields. On the other hand, our results are consistent with the theoretical background on foraging behaviour. Optimal foraging theory (Stephens and Krebs 1986; Kramer 2001) predicts that birds should prefer foraging in larger patches (larger fields). Other authors have also found that geese preferentially forage in larger fields (e.g. Gill 1996; McKay et al. 2006) as well as in more intensively used farmland (Fox et al. 2005). However, we are not aware of any earlier studies showing that crop diversity negatively affected foraging site choice by geese during migration. Thus, geese are one of the few examples of species which may benefit from intensive agriculture (Van Eerden et al. 1996; Fox et al. 2005). However, site choice by geese is inevitably different from that of the declining populations of farmland birds which are mostly territorial during the breeding season. Goose flocks are not territorial and may move long distances to find suitable foraging sites. Therefore, it would be 
interesting to study the effects of habitat diversity on foraging site selection by geese on larger or multiple spatial scales. In our study, we measured crop diversity in a 500-m radius, which is a rather small scale compared to the actual movement of geese. However, all management practices (e.g. changing crop type, time of ploughing) are cheaper and easier to implement at smaller spatial scales (Mouysset et al. 2011).

Consequences for goose conservation and farmland management

Geese are considered to be both species of conservation interest and pests of agriculture (Jepsen 1991; Jensen et al. 2008). There is a clear need to manage land in such a way as to alleviate this conflict (Jensen et al. 2008). A study on the Pink-footed Goose in Norway noted that to achieve this goal, the areas where migrating geese stop to forage should first be identified (Jensen et al. 2008). Such locations should then be designated as foraging refuges for geese and payments subsequently made to farmers (who agree not to disturb foraging geese) active in or near these locations (Jensen et al. 2008). Our results suggest that for such designated foraging refuges to remain attractive to geese, management programmes should consider implementing a number of measures, including larger field size in an open landscape guaranteeing visibility and the absence of human disturbance (fields far from roads and human settlements) (see also Jensen et al. 2008). Additionally, the major crop should be maize (and also beet and rape). To reduce damage to winter cereals, farmers should increase the length of time geese can spend on stubbles (Gill 1996) and increase the area of stubble by leaving maize, beet and rape stubbles in the fields for longer periods of time.

However, some farmers may not be willing to support management policies that benefit geese due to their potential to damage crops (Kahl and Samson 1984; Jensen et al. 2008). Unexpectedly, scaring of foraging geese only enhances the conflict and proportion of farmland impacted by geese, as has been convincingly demonstrated for Pinkfooted Goose (Jensen et al. 2008). Therefore, other solutions for the goose problem must be found. We suggest that farmers may diversify their crops and reduce field size in areas heavy impacted by geese. As we have shown, such an approach is likely to discourage geese from foraging on vulnerable cereal fields and, additionally, should have positive effects on other farmland taxa (smaller birds, pollinating insects, weeds; Whittingham and Devereux 2008). The recommendations above may be easily incorporated into various agri-environment schemes; as such, farmers might benefit financially from both scenarios (Jensen et al. 2008; Crabtree et al. 2010).

Our recommendations are of major importance from the perspective of farmland management for geese in Poland and other countries in Eastern Europe that have recently joined the European Union (EU). These new members of the EU adopted the Common Agricultural Policy that was created on the basis of experience gathered mostly in the countries of Western Europe. There is a great concern that adoption of that common policy will lead to more intensive agriculture in the former traditionally managed farmlands of Eastern Europe (Báldi and Batáry 2011; Tryjanowski et al. 2011). The policy favours large fields and has already led to lower habitat diversity in Western Europe and, consequently, to declines in biodiversity (e.g. Burel and Bradbury 1995; Gregory et al. 2004; Donald et al. 2006). However, from the perspective of migrating geese, these changes seem to be favourable, and one may expect that the size of the goose population will increase, which has the potential to also increase the conflicts between farmers and geese.

Acknowledgements We thank three anonymous referees for their constructive criticism of the manuscript.

Open Access This article is distributed under the terms of the Creative Commons Attribution Noncommercial License which permits any noncommercial use, distribution, and reproduction in any medium, provided the original author(s) and source are credited.

\section{Appendix}

See Table 5. 


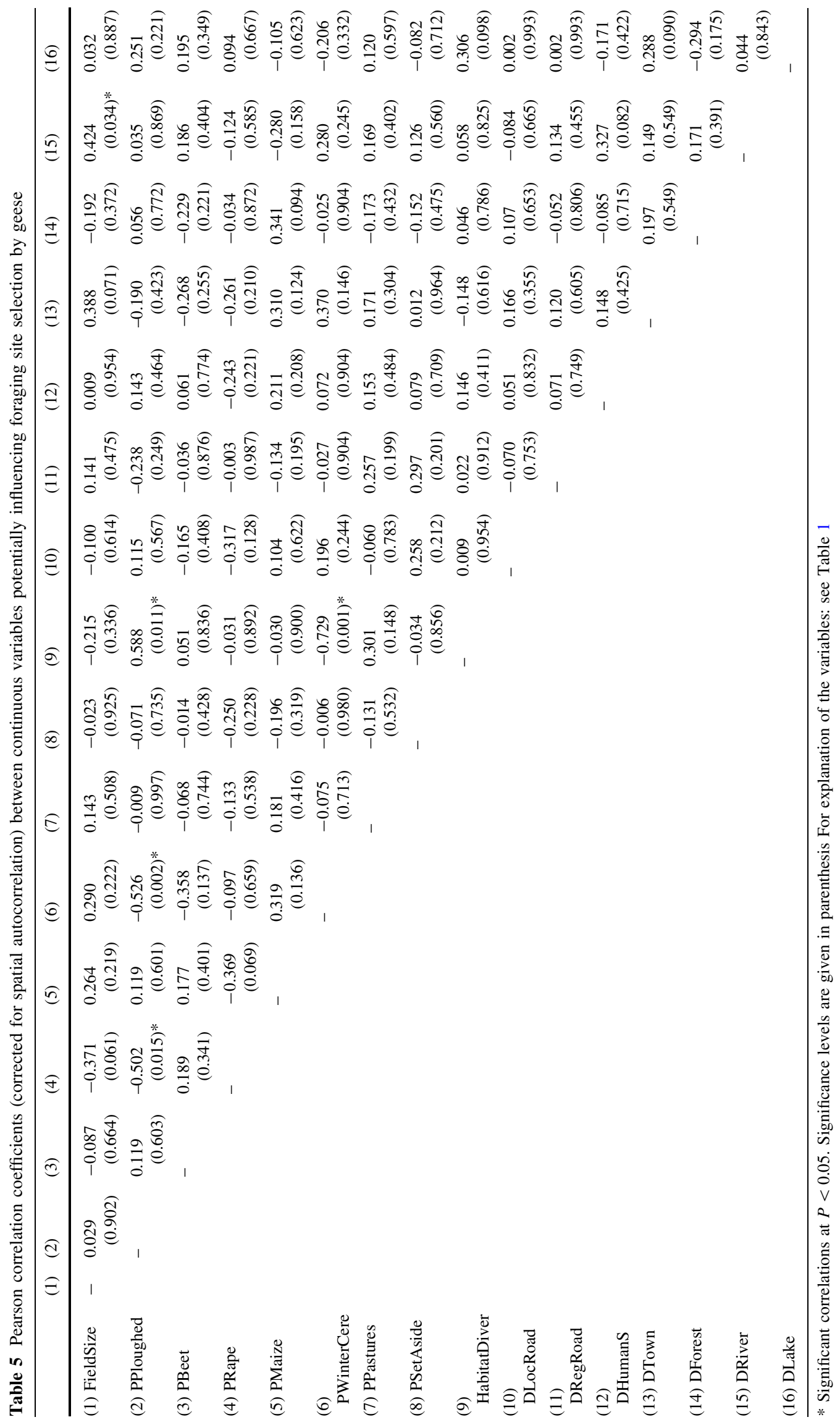




\section{References}

Alerstam T (2011) Optimal bird migration revisited. J Ornithol 152 (Suppl 1):S5-S23

Andersson A, Follestad A, Nilsson L, Persson H (2001) Migration patterns of Nordic greylag geese Anser anser. Ornis Svecica 11:19-58

Báldi A, Batáry P (2011) The past and future of farmland birds in Hungary. Bird Study 58:365-377

Batáry P, Fischer J, Báldi A, Crist TO, Tscharntke T (2011) Does habitat heterogeneity increase farmland biodiversity? Front Ecol Environ 9:152-153

Bauer S, Van Dinther M, Høgda K-A, Klaassen M, Madsen J (2008) The consequences of climate-driven stop-over sites changes on migration schedules and fitness of Arctic geese. J Anim Ecol 77:654-660

Benton TG, Vickery JA, Wilson JD (2003) Farmland biodiversity: is habitat heterogeneity the key? Trends Ecol Evol 18:182-188

Burel F, Bradbury J (1995) Species biodiversity in changing agricultural landscapes: a case study in the Pays d'Auge, France. Agric Ecosyst Environ 55:193-200

Cody ML (1985) Habitat selection in birds. Academic Press, New York

Crabtree B, Humphreys L, Moxey A, Wernham C (2010) Review of goose management policy in Scotland. BTO, Stirling

Cresswell JE, Osborne JL (2004) The effect of patch size and separation on bumblebee foraging in oilseed rape: implications for gene flow. J Appl Ecol 41:539-546

Donald PF, Green RE, Heath MF (2001) Agricultural intensification and the collapse of Europe's farmland bird populations. P Roy Soc Lond B Bio 268:25-29

Donald PE, Sanderson FJ, Burfield IJ, van Bommel FPJ (2006) Further evidence of continent-wide impacts of agricultural intensification on European farmland birds, 1990-2000. Agric Ecosyst Environ 116:189-196

Dormann CF, McPherson JM, Araújo MB, Bivand R, Bolliger J, Carl G, Davies RG, Hirzel A, Jetz W, Kissling WD, Kühn I, Ohlemüller R, Peres-Neto PR, Reineking B, Schröder B, Schurr FM, Wilson R (2007) Methods to account for spatial autocorrelation in the analysis of species distributional data: a review. Ecography 30:609-628

Drent R, Fox A, Stahl J (2006) Travelling to breed. J Ornithol $147: 122-134$

Duriez O, Bauer S, Destin A, Madsen J, Nolet BA, Stillman RA, Klaassen M (2009) What decision rules might pink-footed geese use to depart on migration? An individual-based model. Behav Ecol 20:560-569

Dutilleul P (1993) Modifying the $t$ test for assessing the correlation between two spatial processes. Biometrics 49:305-314

European Parliament and the Council of the European Union (2009) Directive 2009/147/EC of the European parliament and of the Council of 30 November 2009 on the conservation of wild birds. Official Journal of the European Union, Brussels

Farmer AH, Wiens JA (1999) Models and reality: time-energy tradeoffs in Pectoral sandpipers (Calidris melanotos) migration. Ecology 80:2566-2580

Fox AD, Madsen J, Boyd H, Kuijken E, Norriss DW, Tombre IM, Stroud DA (2005) Effects of agricultural change on abundance, fitness components, and distribution of two arctic-nesting goose populations. Glob Change Biol 11:881-893

Frederick RB, Klaas EE (1982) Resource use and behaviour of migrating snow geese. J Wildl Manage 46:601-614

Fuller RJ, Hinsley SA, Swetnam RD (2004) The relevance of nonfarmland habitats, uncropped areas and habitat diversity to the conservation of farmland birds. Ibis 146:22-31
Gill JA (1996) Habitat choice in pink-footed geese: quantifying the constraints determining winter site use. J Appl Ecol 23:884-892

Gill JA, Watkinson AR, Sutherland WJ (1997) Causes of the redistribution of Pink-footed Geese Anser brachyrhynchus in Britain. Ibis 139:497-503

Gregory RD, Noble DG, Custance J (2004) The state of play of farmland birds: population trends and conservation status of lowland farmland birds in the United Kingdom. Ibis 146(Suppl 2): $1-13$

Grubbs F (1969) Procedures for detecting outlying observations in samples. Technometrics 11:1-21

Guglielmo CG (2010) Move that fatty acid: fuel selection and transport in migratory birds and bats. Integr Comp Biol 50:336-345

International BirdLife (2004) Birds in Europe: population estimates, trends and conservation status. BirdLife Conservation Series No. 12. BirdLife International, Cambridge

Jankowiak J, Szpakowska B, Bienkowski J (2003) Ecological aspects of transformation in Poland's agriculture based on the Wielkopolska Region. AMBIO 32:423-428

Jankowiak L, Antczak M, Tryjanowski P (2008) Habitat use, food and the importance of poultry in the diet of the red fox Vulpes vulpes in extensive farmland in Poland. World Appl Sci J 4:886-890

Jensen RA, Wisz MS, Madsen J (2008) Prioritizing refuge sites for migratory geese to alleviate conflicts with agriculture. Biol Conserv 141:1806-1818

Jepsen PU (1991) Crop damage and management of the Pink-footed Goose Anser brachyrhynchus in Denmark. Ardea 79:191-194

Jonker RM, Eichhorn G, van Langevelde F, Bauer S (2010) Predation danger can explain changes in timing of migration the case of the barnacle goose. PLoS One 5:e11369

Kahl BR, Samson FB (1984) Factors affecting yield of winter wheat grazed by geese. Wildl Soc Bull 12:256-262

Klaassen M, Bauer S, Madsen J, Tombre I (2006) Modelling behavioural and fitness consequences of disturbance for geese along their spring flyway. J Appl Ecol 43:92-100

Kramer DL (2001) Foraging behavior. In: Fox CW, Roff DA, Fairbairn DJ (eds) Evolutionary ecology: concepts and case studies. Oxford University Press, New York, pp 232-246

Lawicki L, Wylegala P, Polakowski M, Wuczyński A, Smyk B (2010) New data on Bean Goose Anser fabalis and White-fronted Goose Anser albifrons migration and wintering in Poland. Goose Bull 11:10-14

Legendre P, Legendre L (1998) Numerical Ecology. Elsevier, New York

Leito A, Truu J, Õunsaar M, Sepp K, Kaasik A, Ojaste I, Mägi E (2008) The impact of agriculture on autumn staging Eurasian Cranes (Grus grus) in Estonia. Agric Food Sci 17:53-62

Liebhold A, Koening WD, Bjørnstad ON (2004) Spatial synchrony in population dynamics. Annu Rev Ecol Evol Syst 35:467-490

Lima SL (1987) Vigilance while feeding and its relation to the risk of predation. J Theor Biol 124:303-316

Lima SL (1998) Stress and decision making under the risk of predation: recent developments from behavioural, reproductive and ecological perspectives. Adv Stud Behav 27:215-290

Lindström Å, Dänhardt J, Green M, Klaassen RHG, Olsson P (2010) Can intensively farmed arable land be favourable for birds during migration? The case of the Eurasian golden plover Pluvialis apricaria. J Avian Biol 41:154-162

Maciusik B, Lenda M, Skórka P (2010) Corridors, local food resources, and climatic conditions affect the utilization of the urban environment by the Black-headed Gull Larus ridibundus in winter. Ecol Res 25:263-272

Madsen J (1985a) Habitat selection of farmland feeding geese in West Jutland, Denmark: an example of a niche shift. Ornis Scand $16: 140-144$ 
Madsen J (1985b) Impact of disturbance on field utilization of pinkfooted geese in West Jutland, Denmark. Biol Conserv 33:53-63

Madsen J, Boertmann D (2008) Animal behavioural adaptation to changing landscapes: Spring-staging geese habituate to wind farms. Landsc Ecol 23:1007-1011

Madsen J, Cracknell G, Fox AD (1999) Goose populations of the Western Palearctic: a review of status and distribution, Wetlands International Publication 48. National Environmental Research Institute, Ronde

McAleece N (1997) BioDiversity professional. The National History Museum/the Scottish Association for Marine Science, London/ Oban. Available at: http://www.nhm.ac.uk/zoology/bdpro

McKay HV, Watola GV, Langton SD, Langton SA (2006) The use of agricultural fields by re-established greylag geese (Anser anser) in England: a risk assessment. Crop Protect 25:996-1003

McNamara JM, Houston AI (1992) Evolutionary stable levels of vigilance as a function of group size. Anim Behav 43:641-658

Mouysset L, Doyen L, Jiguet F, Allaire G, Leger F (2011) Bio economic modeling for a sustainable management of biodiversity in agricultural lands. Ecol Econ 70:617-626

Nagy S, Nagy K, Szép T (2009) Potential impact of EU accession on common farmland bird populations in Hungary. Acta Ornithol $44: 37-44$

Newton I (2006) Can conditions experienced during migration limit the population levels of birds? J Ornithol 147:146-166

Nilsson L, Persson H (1991) Selection and exploitation of feeding areas by staging and wintering geese in southernmost Sweden. Ornis Svecica 1:81-92

Nilsson L, Persson H (2000) Changes in field choice among staging and wintering geese in southwestern Scania, South Sweden. Ornis Svecica 10:161-169

Olko J, Wierzbowska I, Hędrzak M (2009) Predation impact of domestic carnivores on wildlife in Poland-results of survey. Theme N5 animals and carnivorous mammals and their role in ecosystems. In: Int Union of Game Biologist 29th Congress. Moscow, pp 242-243 (part 1)

Olsson O, Bruun M, Smith HG (2002) Starling foraging success in relation to agricultural land-use. Ecography 25:363-371

Pita R, Mira A, Moreira F, Morgado R, Beja P (2009) Influence of landscape characteristics on carnivore diversity and abundance in Mediterranean farmland. Agric Ecosyst Environ 132:57-65

Prop J, Black JM, Shimmings P, Owen M (1998) The spring range of barnacle geese Branta lecopsis in relation to changes in land management and climate. Biol Conserv 86:339-346

Quinn GP, Keough MJ (2002) Experimental design and data analysis for biologists. Cambridge University Press, Cambridge

Randler C (2006) Disturbances by dog barking increase vigilance in Coot Fulica atra. Eur J Wildl Res 52:265-270

Rangel TF, Diniz-Filho JAF, Bini LM (2010) SAM: a comprehensive application for spatial analysis in macroecology. Ecography 33:46-50

Raveling D (1979) The annual energy cycle of the cackling Canada goose. In: Jarvis L, Bartonek JC (eds) Management and biology of Pacific flyway Geese: a symposium. OSU Book stores, Cornwallis, pp 81-93

Reed A, Chapdelaine G, Dupuis P (1977) Use of farmland in spring by migrating Canada Geese in the St. Lawrence Valley, Quebec. J Appl Ecol 14:667-680

Reif J, Štastný K, Bejček V (2010) Contrasting effects of climatic and habitat changes on birds with northern range limits in central Europe as revealed by an analysis of breeding bird distribution in the Czech Republic. Acta Ornithol 45:83-90

Roder F, Bijlsma R, Klomp J (2008) Second breeding case of Whitetailed Eagle Haliaeetus albicilla in The Netherlands (in Dutch with English abstract: Tweede broedgeval van de Zeearend Haliaeetus albicilla in Nederland). De Takkeling 16:100-123
Rodríguez-Teijeiro JD, Sardà-Palomera F, Nadal J, Ferrer X, Ponz C, Puigcerver M (2009) The effects of mowing and agricultural landscape management on population movements of the common quail. J Biogeogr 36:1891-1898

Roomen M, van Madsen J (1992) Waterfowl and agriculture: review and future perspective of the crop damage conflict in Europe. IWRB Special Publication No 21. IWRB, Slimbridge

SAS Institute (2010) JMP 9. SAS Institute, Cary

Sebastian-González E, Sanchez-Zapata JA, Botella F (2010) Agricultural ponds as alternative habitat for waterbirds: spatial and temporal patterns of abundance and management strategies. Eur J Wildl Res 56:11-20

Simpson EH (1949) Measurement of diversity. Nature 163:688

Sirot E (2010) Should risk allocation strategies facilitate or hinder habituation to nonlethal disturbance in wildlife? Anim Behav 80:737-743

Skórka P, Lenda M, Martyka R, Tworek S (2009) The use of metapopulation and optimal foraging theories to predict movement and foraging decisions of mobile animals in heterogeneous landscapes. Landsc Ecol 24:599-604

Spilling E, Bergmann HH, Meier R (1999) Flock sizes in foraging White-fronted and Bean Geese in the Elbe valley and their effects on flight distance and time budget. J Ornithol 140:325-334

Stephens DW, Krebs JR (1986) Foraging theory. Princeton, Princeton University Press

Surmacki A (2005) Do dense and fast growing crops provide foraging habitats for insectivorous birds? Pol J Ecol 53:129-133

Tinkler E, Montgomery WI, Elwood RW (2009) Foraging ecology, fluctuating food availability and energetics of wintering brent geese. J Zool 278:313-323

Tombre IM, Madsen J, Tømmervik H, Haugen KH, Ethórsson E (2005) Influence of organised scaring on distribution and habitat choice of geese on pastures in Northern Norway. Agric Ecosys Environ 111:311-320

Tryjanowski P, Gołdyn B, Surmacki A (2002) Influence of the red fox (Vulpes vulpes) on distribution and number of breeding birds in an intensively used farmland. Ecol Res 17:395-399

Tryjanowski P, Hartel T, Baldi A, Szymanski P, Tobolka M, Herzon I, Golawski A, Konvicka M, Hromada M, Jerzak L, Kujawa K, Lenda M, Orlowski G, Panek M, Skórka P, Sparks TH, Wuczyński A, Żmihorski M (2011) Conservation of farmland birds faces different challenges in Western and Central-Eastern Europe. Acta Ornithol 46:1-12

Van der Graaf AJ, Stahl J, Veen GF, Havinga RM, Drent RH (2007) Patch choice of avian herbivores along a migration trajectoryfrom temperate to Arctic. Basic Appl Ecol 8:354-363

Van Eerden MR, Zijlstra M, Van Roomen M, Timmerman A (1996) The response of Anatidae to changes in agricultural practice: long-term shifts in the carrying capacity of wintering waterfowl. Gibier Faune Sauvage 13:706

Wang Z, Li Z, Beauchamp G, Jiang Z (2011) Flock size and human disturbance affect vigilance of endangered red-crowned cranes (Grus japonensis). Biol Conserv 144:101-105

Whittingham MJ, Devereux CL (2008) Changing grass height alters foraging site selection by wintering farmland birds. Basic Appl Ecol 9:779-788

Wilk T, Jujka M, Krogulec J, Chylarecki P (2010) Important bird areas of international importance in Poland (in Polish with English summary). OTOP, Marki

Wilson JD, Whittingham MJ, Bradbury RB (2005) The management of crop structure: a general approach to reversing the impacts of agricultural intensification on birds? Ibis 147:453-463 